\title{
Time-dependency of edema-based assessment of area-at-risk in reperfused acute myocardial infarction
}

\author{
Veronica LM Rundell ${ }^{1 *}$, Xiangzhi Zhou', Avinash Kali', Ying Liu', Richard Tang ${ }^{1}$, Rachel A Klein ${ }^{1}$, Andreas Kumar², \\ Rohan Dharmakumar'
}

From 2011 SCMR/Euro CMR Joint Scientific Sessions

Nice, France. 3-6 February 2011

\section{Introduction}

Relative edema volume, computed from T2-based CMR images, has been used to define the Area-At-Risk in myocardial infarction and in the determination of salvagable myocardium in patients. Following infarction, edema presents as hyperintense regions in T2-weighted CMR, however, the literature reports disparate data resulting from delayed imaging and type of MR acquisition.

\section{Purpose}

To investigate the time course and extent of myocardial edema in reperfused myocardial infarction on the basis of T2 maps and T2-weighted STIR imaging.

\section{Methods}

Cardiac MR was used to investigate the development and persistence of edema volume increases in the acute postinfarct period using both $\mathrm{T}_{2}$-weighted STIR imaging and $\mathrm{T}_{2}$ maps. LAD instrumented canines $(\mathrm{n}=9)$ underwent three hours of no-flow ischemia followed by reperfusion and were studied [using Siemens $1.5 \mathrm{~T}$ Espree scanner] at five time points (before and during ischemia and 2, 5, 7 and 56 days post-reperfusion). Scan parameters for $\mathrm{T}_{2}$-STIR acquisitions were: $\mathrm{TE}=64 \mathrm{~ms}, \mathrm{TR}=2-3 \mathrm{R}-\mathrm{R}$ intervals, resolution $=0.9 \times 0.9 \times 8.0 \mathrm{~mm}^{3} . \mathrm{T}_{2}$ maps were computed from multiple $\mathrm{T}_{2}$-prepared acquisitions with different preparation times $(0,24$, and $55 \mathrm{~ms})$ with spatial-resolution of $1.0 \times 1.0 \times 8.0 \mathrm{~mm}^{3}$. Late-enhancement imaging confirmed LAD infarction. Areas of interest were determined as follows: For $\mathrm{T} 2$ maps - region with $\mathrm{T}_{2}$ values greater than 2SD from remote territories; and for $\mathrm{T}_{2}$-STIR

${ }^{1}$ Northwestern University, Chicago, IL, USA

Full list of author information is available at the end of the article images- regions exceeding 2SD of the signal intensity of the remote regions. Edema volume was computed as highlighted areas multiplied by imaging slice thickness. Percent volume of edema was computed relative to total myocardial volume. Results are reported as mean \pm SEM for each time point.

\section{Results}

Percent volume of edema (Area-At-Risk) - $\mathbf{T}_{\mathbf{2}}$ Maps: Pre-ischemia: $0.8 \pm 0.4 \%$; Ischemia: $2.5 \pm 1.4 \%$; Day 2: 18.3

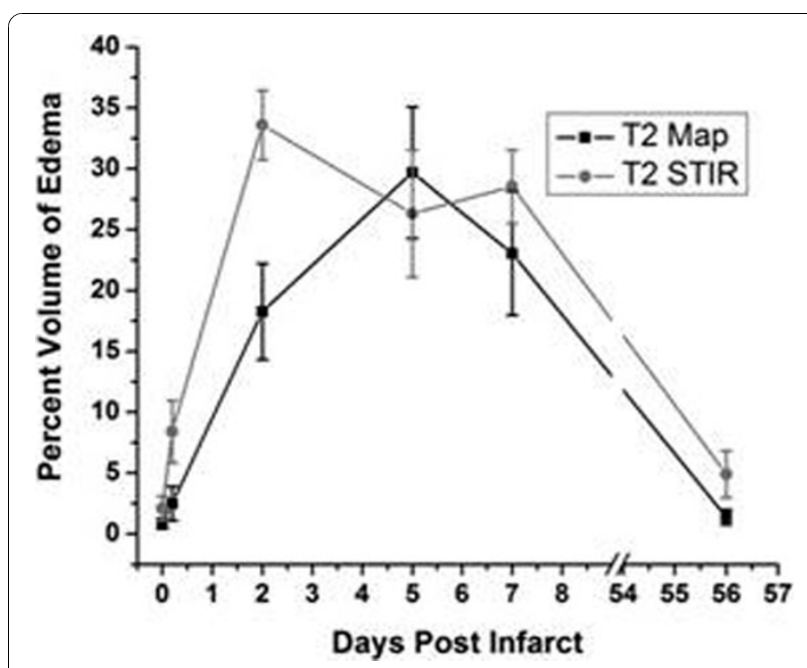

Figure 1 Time evolution of edema volume in a canine model of ischemia-reperfusion injury measured on the basis of changes in T2 and signal intensity on T2-STIR images: Note that the percent volume of edema measured from T2 maps is generally lower than that from T2 STIR and that the edema volume is variable within the acute period of tissue injury and resolves to near baseline levels by week 8 .

\section{C) Biomed Central}

C 2011 Rundell et al; licensee BioMed Central Ltd. This is an open access article distributed under the terms of the Creative Commons Attribution License (http://creativecommons.org/licenses/by/2.0), which permits unrestricted use, distribution, and reproduction in any medium, provided the original work is properly cited. 
$\pm 3.9 \%$; Day 5: 29.7 $\pm 5.4 \%$; Day7: $23.0 \pm 5.1 \%$; and Day 56: $1.4 \pm 0.6 \%$. $\mathbf{T}_{2}$-STIR: Pre-ischemia: $2.1 \pm 1.0 \%$; Ischemia: 8.4 $\pm 2.6 \%$; Day 2: $33.6 \pm 2.9 \%$; Day 5: $26.1 \pm 5.2 \%$; Day7: 28.5 $\pm 3.0 \%$; and Day 56: $4.9 \pm 1.9 \%$. $\mathrm{p}<0.01$ by ANOVA. $\mathrm{T}_{2}$ maps showed a continuous rise in relative edema volume post reperfusion that peaked at day 5 . Although edema volume decreased by day 7 , it remained significantly elevated from pre-ischemic levels. In $\mathrm{T}_{2}$-STIR analysis, edema volume rose rapidly, peaking at day 2 and remaining elevated throughout the acute study period. $\mathrm{T}_{2}$-STIR images showed an earlier peak in edema volume compared to that determined from $\mathrm{T}_{2}$ maps. Both measures demonstrated regression of edema after 56 days. Figure 1.

\section{Conclusion}

This data indicates that the time following ischemiareperfusion injury, as well as the mode of MR interrogation, are critical variables in the determination of Area-at-Risk.

Author details

${ }^{1}$ Northwestern University, Chicago, IL, USA. ${ }^{2}$ Laval University, Quebec City, QC, Canada.

Published: 2 February 2011

doi:10.1186/1532-429X-13-S1-P111

Cite this article as: Rundell et al.: Time-dependency of edema-based assessment of area-at-risk in reperfused acute myocardial infarction. Journal of Cardiovascular Magnetic Resonance 2011 13(Suppl 1):P111.
Submit your next manuscript to BioMed Central and take full advantage of:

- Convenient online submission

- Thorough peer review

- No space constraints or color figure charges

- Immediate publication on acceptance

- Inclusion in PubMed, CAS, Scopus and Google Scholar

- Research which is freely available for redistribution

Submit your manuscript at www.biomedcentral.com/submit
C Biomed Central 